\title{
Breeding as a Tool to Control late Blight in Tomato
}

\author{
Dariva FD, Ferreira MG, Pessoa HP and Alves FM* \\ Department of Fitotecnia, Universidade Federal de Viçosa, Brazil
}

Submission: April 30, 2018; Published: May 17, 2018

*Corresponding author: Alves FM, Department of Fitotecnia, Universidade Federal de Viçosa, Campus Viçosa, Viçosa, MG 36570-900, Brazil, Email: flaviamarialves@gmail.com

Keywords: Phytophthora infestans; Genetics; Vegetable breeding

\section{Introduction}

Diseases cause significant economic losses in tomato crops [1]. Late blight caused by the oomycete Phytophthora infestans (Mont.) de Bary is one of the most common and destructive diseases that affects tomato plants worldwide [2]. Yield losses resulting from tomato late blight can reach up 100\% [3]. In the United States, it is estimated that late blight costs US\$ 210 million annually when crop losses and fungicide use are taken into account [2].

P. infestans causes irregularly shaped, water-soaked lesions on young leaves at the top part of the plant and, as the disease progresses, the affected leaves become necrotic and die. Brown lesions can be observed on stems, and circular greasy lesions on fruits (www.usablight.org/node/29; [2]. Disease progress rate is so high that it could compromise the whole field just a few days after the epidemy has started. Each lesion could produce up until 300 thousand new sporangia a day which results on a quick propagation of the disease [2].

The pathogen is able to reproduce both sexually and asexually [3]. Asexual cycle allows rapid populational growth inside plant tissues of susceptible hosts. Sporangia are produced on sporangiophore that grows from infected tissues. Sporangia are dehiscent, especially in response to changes on relative humidity, and can be easily dispersed to other plant tissues [4]. Sporangia germination occurs either through the direct formation of germ tubes under high temperatures (around $20-25^{\circ} \mathrm{C}$ ) and high relative humidity (above $90 \%$ ) or by zoosporogenesis under cool temperatures (around $10 \mathrm{e} 15^{\circ} \mathrm{C}$ ) [5].

Late blight control is often achieved through application of protectant and penetrant fungicides, usually 15 to 25 fungicide applications are made per season [6]. This intense use of fungicides increases total production costs beyond causing serious problems to human health, including higher concentration of toxic residues on fruits and increased exposure of operators to chemicals, and pollution of soil and water resources through product leaching. Moreover, it may cause new and more aggressive forms of the pathogen to appear [7].

\section{Discussion}

The use of cultivars carrying resistance genes against LB is therefore considered a more environmentally-friendly, costeffective alternative to control this disease. Studies regarding genetic resistance to P. Infestans have been target of various tomato breeding programs for many years. According these studies, resistance to LB in tomato plants is very complex and may involve the expression of one or few genes (qualitative resistance) or even the expression of various genes (quantitative resistance).The resistance to LB refers to a trait of quantitative inheritance controlled by aproximatelly 28 genes [8].

Studies involving the monogenic inheritance of resistance to LB in tomato plants are associated with the discovery of resistance alleles in tomato wild species, especially S.pimpinellifolium [3]. In S. pimpinellifolium, three resistance genes were found, and are located on chromosomes 7(Ph-1), 10(Ph-2), and 9(Ph-3) [3]. $\mathrm{Ph}-1$, a completely dominant gene, was the first found. This gene is known for conferring resistance against tomato race-0 $\left(\mathrm{T}_{0}\right)$, however, it was rapidly overcome by new races of the pathogen. The $\mathrm{Ph}-2$ gene provides only partial resistance to tomato plants. A disadvantage is that instead of blocking the disease, $\mathrm{Ph}-2$ only reduces its development rate and hence may not be effective when more aggressive isolates are present [9]. Resistance provided by $\mathrm{Ph}-3$, on the other hand, has been reported to be considerably effective against a wide range of P.infestans isolates. In terms of inheritance, both $\mathrm{Ph}-2$ and $\mathrm{Ph}-3$ display incomplete dominance $[3,10]$.

Years later, other P. infestans resistance genes were identified on chromossome 2(Ph-4) [11] and no chromossome $1(\mathrm{Ph}-5)$ [2]. However, reports confirmed that new isolates of P. infestans have already overcome the resistant conferred by these genes $[10,12]$. For this reason, breeding programs should rely on more durable 
resistance mechanisms such as the introgression of several resistance genes (quantitative resistance) [13].

Successful introgression of LB resistance genes in elite materials is highly dependent on selecting the right genitors to be used on the crosses [13]. In tomato crops, the methodology most used was proposed by Griffingin [14]. This methodology estimates both general and specific combining abilities between parents and hybrid combinations through diallelic crosses. Introgression of genes controlling desirable traits from wild species to the cultivated tomato is often facilitate when genotype-phenotype associations mediated by molecular markers are made. This process is known as QTL mapping [15]. When chromosomic locations of QTL's conferring desirable characteristics are known, marker-assisted selection (MAS) is used, making the process of creating a new cultivar easier and less time-consuming.

QTL mapping also allows the formation of nearly-isogenic lines (NILs) that refers to those lineages carrying only a gene donated by a wild genitor (Monforte and Tanksley 2000). In tomato, NILs were developed through inter-specific crosses [16]. In general, NILs possess only a small percentage of the donor genome (less than $5 \%$ ), that are commonly modified by several characteristics, including some undesirable effects. These modifications are needed to reduce fragment length in order to assess if the undesirable effects are due to linkage to other genes, pleiotropy or a single-locus. After canceling undesirable effects, introgression processes may be more effective in plant breeding. It also has the advantage to avoid losing desirable genes through recombination after the generations, what will make it possible to introduce them in elite germplasm using MAS $[17,18]$.

\section{Conclusion}

These techniques will allow the development of resistant cultivars in an increased rate. It is highly important to develop late blight resistant cultivars since it will increase yield at the same time that it will reduce fungicide applications and hence the problems caused by their use.

\section{References}

1. Nowicki M, Kozik EU, Foolad MR (2013) Late blight of tomato Translational Genomics for Crop Breeding: Biotic Stress, John Wiley \& Sons, Inc., USA, pp. 241-265.

2. Foolad M, Merk H, Ashrafi H (2008) Genetics, genomics and breeding of late blight and early blight resistance in tomato. Journal Critical Reviews in Plant Sciences 27(2): 75-107.

3. Nowicki M, Foolad MMR, Nowakowska M, Kozik EUE (2012) Potato and tomato late blight caused by Phytophthora infestans: An overview of pathology and resistance breeding. Plant Dis 96(1): 4-17.
4. Fry W (2008) Phytophthora infestans: the plant (and R gene) destroyer Mol Plant Pathol 9(3): 385-402.

5. Lima MA, Maffia LA, Barreto RW, Mizubuti ESG (2009) Phytophthora infestans in a subtropical region: survival on tomato debris, temporal dynamics of airborne sporangia and alternative hosts. Plant Pathol 58: 87-99.

6. Fiorini CVA, Silva DJH da, Silva FF e, Mizubuti ESG, Alves DP, et al. (2010) Agrupamento de curvas de progresso de requeima, em tomateiro originado de cruzamento interespecífico. Pesqui Agropecuária Bras 45(10): 1095-1101.

7. Duarte H, Zambolim L, Waldir W (2007) ARTIGOS Manejo da requeima do tomateiro industrial empregando sistema de previsão. Summa Phytopathol 33(4): 328-334.

8. Abreu F, Silva D, Cruz C, Mizubuti E (2008) Inheritance of resistance to Phytophthora infestans (Peronosporales, Pythiaceae) in a new source of resistance in tomato (Solanum sp. (formerly Lycopersicon sp.) Genet Mol Biol 31(2).

9. Zhang C, Liu L, Wang X, Vossen J, Li G, et al. (2014) The Ph-3 gene from Solanum pimpinellifolium encodes CC-NBS-LRR protein conferring resistance to Phytophthora infestans. Theor Appl Genet 127(6): 13531364.

10. Chen CH, Sheu ZM, Wang TC (2008) Host Specificity and TomatoRelated Race Composition of Phytophthora infestans Isolates in Taiwan during 2004 and 2005. Plant Dis 92(5): 751-755.

11. Li J, Luan Y, Liu Z (2015) SpWRKY1 mediates resistance to Phytophthora infestans and tolerance to salt and drought stress by modulating reactive oxygen species homeostasis and expression of defense-related genes in tomato. Plant Cell, Tissue Organ Cult 123(1): 67-81.

12. Miranda BEC de, Suassuna ND, Reis A (2010) Mating type, mefenoxam sensitivity, and pathotype diversity in Phytophthora infestans isolates from tomato in Brazil. Pesqui Agropecuária Bras 45: 671-679.

13. Elsayed A, da Silva D, Mizubuti E, Carneito C (2011) Combing the monogenic and polygenic resistant genes to late blight in tomato. J Plant 3(10): 251-259.

14. Griffing B (1956) Concept of general and specific combining ability in relation to diallel crossing system. Aust J Biol Sci 9: 463-493.

15. Haggard JE, Johnson EB, St Clair DA (2013) Linkage relationships among multiple QTL for horticultural traits and late blight (P. infestans) resistance on chromosome 5 introgressed from wild tomato Solanum habrochaites. G3 (Bethesda) 3(12): 2131-2146.

16. Tanksley SD, Grandillo S, Fulton TM, Zamir D, Eshed Y, et al. (1996) Advanced backcross QTL analysis in a cross between an elite processing line of tomato and its wild relative L. pimpinellifolium. Theor Appl Genet 92(2): 213-224.

17. Monforte AJ, Tanksley SD (2000) Fine mapping of a quantitative trait locus (QTL) from Lycopersicon hirsutum chromosome I affecting fruit characteristics and agronomic traits: Breaking linkage among QTLs affecting different traits and dissection of heterosis for yield. Theor Appl Genet 100(3-4): 471-479.

18. Xu Y, Crouch JH (2008) Marker-Assisted Selection in Plant Breeding: From Publications to Practice. Crop Sci 48(2): 391-407. 
This work is licensed under Creative Commons Attribution 4.0 License DOI: 10.19080/JOJHA.2018.01.555567
- Quality Editorial service

- Swift Peer Review

- Reprints availability

- E-prints Service

- Manuscript Podcast for convenient understanding

- Global attainment for your research

- Manuscript accessibility in different formats ( Pdf, E-pub, Full Text, Audio)

- Unceasing customer service

Track the below URL for one-step submission https://juniperpublishers.com/online-submission.php 